\title{
Variations in Antibiograms and Plasmid Profiles among Multiple Isolates of Staphylococcus intermedius from Pyoderma in Dogs
}

Furunculosis is defined as an inflammation involving epidermis and corium, usually derived as a pathological continuum of folliculitis and perifolliculitis. Furunculosis is frequently seen in dogs (Muller et al. 1989). Canine furunculosis is a complex, multifactorial disorder and various factors have been suggested to be involved in its pathogenesis: bacterial, fungal, and parasitic infections (Muller et al. 1989), immunosuppression, impaired neutrofil function (Latimer et al. 1982, Muller et al. 1989), endocrine abnormalities, seborrhea or allergic conditions (Muller et al. 1989). The most common microbiological finding is Staphylococcus intermedius (Muller et al. 1989), a Staphylococcus species which has also been associated with other pathological conditions in dogs, e.g. uterine and urinary tract infections, respiratory tract infections, mastitis, and otitis externa (Biberstein et al. 1984). Usually, staphylococcal pyoderma responds to appropriate antibiotic therapy and may completely resolve. However, the disease often recurs subsequent to termination of treatment. Some dogs exhibiting recurrent staphylococcal pyoderma are repeatedly presented to the veterinarians by the progressively frustrated owner. The dogs are usually prescribed topical treatment as well as systemic antibiotics according to the result of bacteriological examination and antibiotic sensitivity test (Codner 1988, Muller et al. 1989). Anti- biotic resistance among $S$. intermedius may complicate the treatment of the disease which may result in fatal bacteriaemia or euthanasia. Autochtonous vaccines, prepared from whole-cells, are frequently used as a supplement in the treatment of long standing canine staphylococcal pyodermas and have been reported to be of some value (DeBoer et al. 1990). Usually, autochtonous vaccines and antibiotic sensitivity testings are made from a single $S$. intermedius isolate from the infected dog.

The purpose of the present study was to investigate if it was possible to isolate 2 or more distinct $S$. intermedius strains from the pathological processes of the single dog suffering from furunculosis. Based on the results the relevance of antibiotic sensitivity testings and autovaccines is discussed.

From 11 dogs with a history of furunculosis the laboratory received skin swabs, collected by the practitioner from a typical lesion of the patient. Sufficient data regarding previous antibiotic therapy of the patients were not available. Swabs were submitted to the laboratory in transport medium (Stuart's medium, Difco No. 9340), streaked onto blod agar plates (Volumbia agar, Oxoid CM331, supplemented with $5 \%$ sterile bovine blood), and incubated overnight at $37^{\circ} \mathrm{C}$ aerobically. Predominant growth on primary plates appeared as beta hemolytic porcelain white colonies. Ten colo- 
nies producing beta hemolysis and with typical colonial appearance were collected at random from each sample and subsequently identified according to the following scheme: Strains giving a positive reaction for catalase, proteae, lipase, heat stable DNase, and negative reaction for oxidase and hyaluronidase, and showing resistance to bacitracin and sensitivity to furazolidone and novobiocin, were identified as $S$. intermedius. The diagnostic tests were carried out according to Devriese \& Hájek (1980). Subsequently, strains were subjected to antibiotic sensitivity testing and plasmid profiling. Strains were tested for sensitivity to penicillin, streptomycin, tetracycline, lincomycin, fucidin, sulphonamides, chloramphenicol, amoxycillin + clavulanate. Sensitivity to diagnostic and therapeutic antibiotics was determined on Iso-Sensitest agar (Oxoid CM471) using a tablet diffusion method according to the manufacturer's guidelines ( $\mathrm{Ca}$ sals \& Pringler 1991). Plasmid DNA was isolated by a modification of the method described by Holmes \& Quigley (1918), using $70 \mu \mathrm{g} / \mathrm{ml}$ lysostaphin (Sigma) for lysis of bacterial cells prior to boiling. Plasmid DNA were subsequently subjected to electrophoresis in $0.8 \%$ ag arose gel.

All of 110 isolates identified as $S$. intermedius were sensitive to fucidin, and amoxycillin + clavulanate. Data for the remaining antibiotics are shown in Table 1 . From 6 patients all 10 $S$. intermedius isolates possessed identical antibiogram patterns while isolates from each of the other 5 patients could be divided in 2 distinct subgroups. Each antibiogram pattern

Table 1. Resistance to antibiotics and plasmid profiles of 10 isolates of Staphylococcus intermedius collected at random from the skin of each of 11 dogs with pyoderma.

\begin{tabular}{|c|c|c|c|}
\hline $\begin{array}{l}\text { Patient } \\
\text { No. }\end{array}$ & $\begin{array}{l}\text { No. of } \\
\text { isolates }\end{array}$ & Antibiotic-resistance pattern ${ }^{a}$ & Plasmid profile $(\mathrm{kb})$ \\
\hline 889 & $\begin{array}{l}8 \\
2\end{array}$ & $\begin{array}{l}\text { pen-strep-linco-sulfa-chlor } \\
\text { sensitive to all }\end{array}$ & $\begin{array}{l}2.3,4.4 \text {, and } 7.1 \\
\text { n.p. }\end{array}$ \\
\hline 890 & 10 & pen-strep-linco-sulfa & 3.0 \\
\hline 891 & 10 & pen & n.p. \\
\hline 896 & 10 & sensitive to all & n.p. \\
\hline 903 & $\begin{array}{l}8 \\
2\end{array}$ & $\begin{array}{l}\text { pen-sulfa } \\
\text { sensitive to all }\end{array}$ & $\begin{array}{l}\text { n.p. } \\
\text { n.p. }\end{array}$ \\
\hline 907 & 10 & sulfa & n.p. \\
\hline 1037 & $\begin{array}{l}8 \\
2\end{array}$ & $\begin{array}{l}\text { pen } \\
\text { sensitive to all }\end{array}$ & $\begin{array}{l}3.4 \\
\text { n.p. }\end{array}$ \\
\hline 1063 & 10 & sensitive to all & $3.0,19.0,34.0$ \\
\hline 1066 & $\begin{array}{l}6 \\
4\end{array}$ & $\begin{array}{l}\text { pen-strep-tet-linco-sulfa-chlor } \\
\text { sulfa }\end{array}$ & $\begin{array}{l}2.3 \\
\text { n.p. }\end{array}$ \\
\hline 1084 & 10 & sensitive to all & 3.0 \\
\hline 1125 & $\begin{array}{l}7 \\
3\end{array}$ & $\begin{array}{l}\text { pen-strep-tet-sulfa } \\
\text { pen }\end{array}$ & $\begin{array}{l}2.3,3.1 \\
2.3,3.4\end{array}$ \\
\hline
\end{tabular}

a) Determined by a tablet diffusion method using antibiotic tablets containing the following diffusible amounts of antibiotics (abbreviation, break point): $5 \mu \mathrm{g}$ penicillin (pen, $\mathrm{R}<23 \mathrm{~mm}$ ), $100 \mu \mathrm{g}$ streptomycin (strep, $\mathrm{R}<23 \mathrm{~mm}$ ), $80 \mu \mathrm{g}$ tetracycline (tetra, $\mathrm{R}<19 \mathrm{~mm}$ ), $19 \mu \mathrm{g}$ lincomycin (linco, $\mathrm{R}<23 \mathrm{~mm}$ ), $400 \mu \mathrm{g}$ fucidin (fuci, $\mathrm{R}<23 \mathrm{~mm}$ ), $240 \mu \mathrm{g}$ sulfonamide (sulfa, $\mathrm{R}<23 \mathrm{~mm}$ ), $60 \mu \mathrm{g}$ chloramphenicol (chlor, $\mathrm{R}<23 \mathrm{~mm}$ ), $30 \mu \mathrm{g}$ amoxycillin $+15 \mu$ g clavulanate $(\mathrm{amc}, \mathrm{R}<22 \mathrm{~mm}$ ).

b) n.p. $=$ no plasmids detected. 
corresponded to a specific plasmid profile in the isolates form a single patient (Table 1). Occurrence of $S$. intermedius isolates of varying antibiogram pattern and plasmid profile on individual patients indicate that more than a single strain of $S$. intermedius can be present in the pathological processes of a dog suffering from staphylococcal pyoderma. This is in accordance with infections with Staphylococcus hyicus in pigs, the ethiologic agent of exudative epidermitis (Wegener 1992).

The presence of several different $S$. intermedius strains on individuals with pyoderma may be of great importance for the correct treatment of the disease. Simultaneous occurrence of strains with different antibiotic resistance or antigenic properties may be crucial for the result of systemic antibiotic treatment or autovaccination. In our laboratory, a tablet diffusion method is used for determination of antibiotic susceptibility. Broth cultures prepared from $10 \mathrm{~S}$. intermedius isolates randomly selected from the material are pooled and inoculated on a single agar plate on which antibiotic tablets are subsequently applied. A single resistant strain among 9 susceptible strains can easily be detected by this method. Only antibiotics which are active against all isolates are prescribed for therapy.

Further investigations should clarify the clonal relationship between isolates from each patient with varying antibiograms. This could be performed using a genotypic typing system, e.g. restriction endonuclease analysis of chromosomal DNA. Furthermore, antibiograms of $S$. intermedius isolates before, during, and after antibiotic treatment of dogs with pyoderma should be investigated, and correlated to the loss or uptake of antibioticresistance plasmids.

In the light of the present findings, it also seems urgent to investigate the presence of common virulence determinants and major antigens of $S$. intermedius, in order to prepare a common vaccine for the prevention of staphylococcal pyoderma in dogs.

\section{Acknowledgement}

The skilfull technical assistance of Miss L. H. Larsen is gratefully acknowledged. This work was supported by a grant from »Fondet til sygdomsbekæmpelse hos vore familiedyr «.

\section{Henrik Caspar Wegener \\ National Veterinary Laboratory \\ 27 Bülowsvej \\ DK-1790 Copenhagen V \\ Denmark}

\section{Karl Pedersen}

Royal Veterinary and Agricultural University

13 Bülowsvej

DK-1870 Frederiksberg C

Denmark.

\section{References}

Biberstein EL, Jang SS, Hirsh DV: Species distribution of coagulase-positive staphylococci in animals. J. clin. Microbiol. 1984, 19, 610-615.

Casals JB, Pringler N: Antibacterial sensitivity tesing using Neo-Sensitabs. Rosco Diagnostica, Taastrup, Denmark, 1991.

Codner EC: Choosing a treatment course for dogs with pyoderma. Vet. Med. 1988, 995-1003.

DeBoer DJ, Moriello KA, Thomas CB, Schultz KT: Evaluation of acommercial bacterin for management of idiopathic recurrent superficial pyoderma in dogs. Amer. J. vet. Res. 1990, 51, 636639.

Devriese LA, Hajek V: A review. Identification of pathogenic staphylococci isolated from animals and foods derived from animals. J. appl. Bacteriol. 1980, 49, 1-11.

Hajek V: Staphylococcus intermedius, a new species isolated from animals. Int. J. syst. Bacteriol. 1976, 26, 401-408.

Holmes DS, Quigley M: A rapid boiling method for the preparation of bacterial plasmids. Anal. Biochem. 1981, 114, 193-197.

Latimer KS, Prasse KW, Dawe DL: A transient deficit in neutrophilic chemotaxis in a dog with recurrent staphylococcal pyoderma. Vet. Pathol. 1982, 19, 223-229. 
Love DN: Antimicrobial susceptibility of staphylococci isolated from dogs. Aust. vet. Practit. 1989, 19, 196-200.

Muller GH, Kirk RW, Scott DW: Small animal dermatology. 4th ed. WB Saunders Company, Philadelphia, 1989.
Wegener, HC: Staphylococcus hyicus epidemiology and virulence in relation to exudative epidermitis in pigs. Ph.D. Thesis, National Veterinary Laboratory, Copenhagen, and Royal Veterinary and Agricultural University, Copenhagen, Denmark, 1992.

(Received June 15, 1992; accepted September 1, 1992).

Reprints may be requected from: H. C. Wegener, National Veterinary Laboratory, 27 Bülowsvej, DK-1790 Copenhagen V, Denmark. 